HEINRICH HEINE 


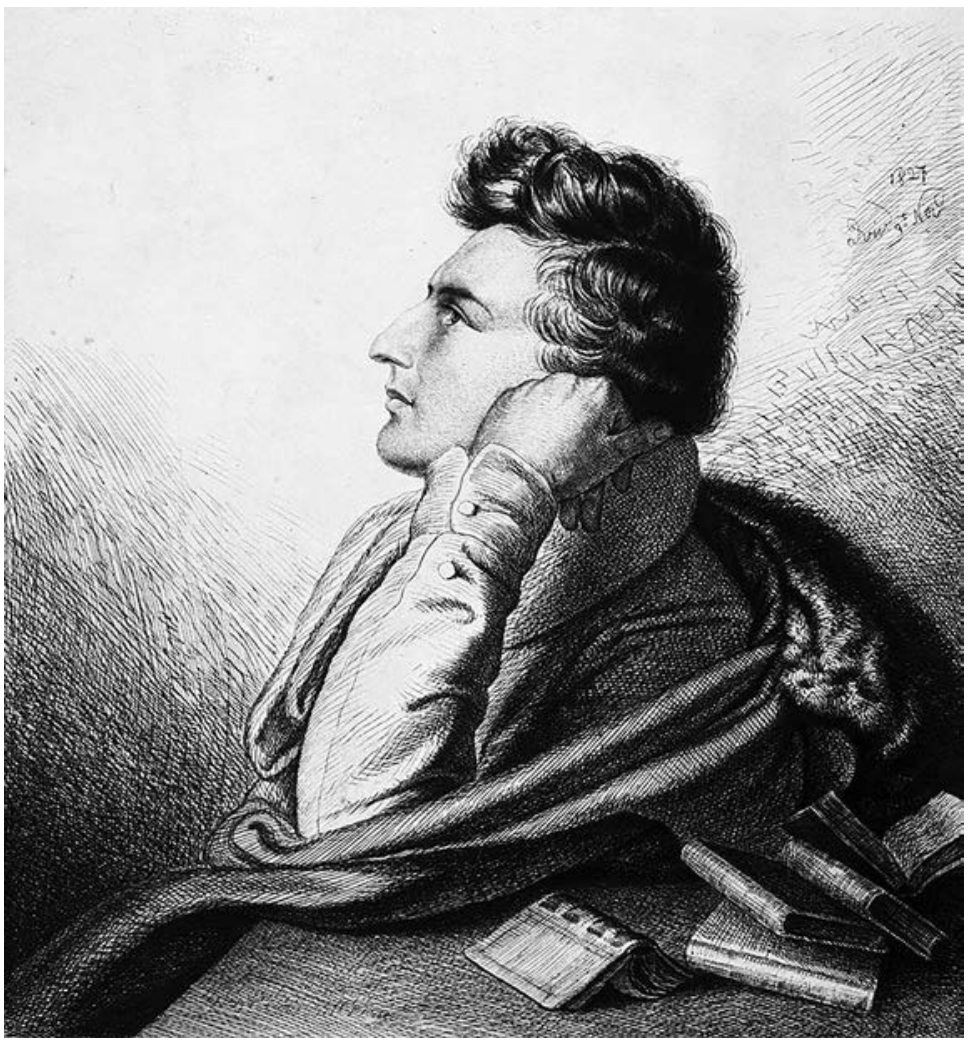




\section{Heinrich Heine}

\section{Writing the Revolution}

GEORGE PROCHNIK

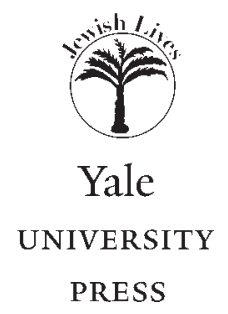

New Haven and London 
Jewish Lives ${ }^{\circledR}$ is a registered trademark of the Leon D. Black Foundation.

\section{Copyright (C) 2020 by George Prochnik.}

All rights reserved.

This book may not be reproduced, in whole or in part, including illustrations, in any form (beyond that copying permitted by Sections 107 and Io8 of the U.S.

Copyright Law and except by reviewers for the public press), without written permission from the publishers.

Yale University Press books may be purchased in quantity for educational, business, or promotional use. For information, please e-mail sales.press@yale.edu (U.S. office) or sales@yaleup.co.uk (U.K. office).

Frontispiece: Ludwig Emil Grimm, Portrait of Heinrich Heine, 1827. Etching (228 $\times$ I9 I mm). Rijksmuseum, Amsterdam (Wikimedia Commons/Public Domain).

Set in Janson Oldstyle type by Integrated Publishing Solutions. Printed in the United States of America.

Library of Congress Control Number: 2020936895

ISBN 978-0-300-23654-5 (hardcover : alk. paper)

A catalogue record for this book is available from the British Library.

This paper meets the requirements of ANSI/NISO Z39.48-1992

(Permanence of Paper).

I0 98765432 I 
For Rebecca 
This page intentionally left blank 